\title{
Effect of Dividend Policy on Financial Performance of Consumer Goods Manufacturing Firms in Nigeria
}

\author{
Ubesie Madubuko Cyril, Emejulu Callistus Emeka, Iyidiobi Felicia Cheluchi \\ Department of Accountancy, Faculty of Management Sciences, Enugu State University of Science and Technology (ESUT), Enugu, Nigeria
}

Email address:

ubesiemadubuko@yahoo.com (U. M. Cyril), calbens66@gmail.com (E. C. Emeka)

\section{To cite this article:}

Ubesie Madubuko Cyril, Emejulu Callistus Emeka, Iyidiobi Felicia Cheluchi. Effect of Dividend Policy on Financial Performance of Consumer Goods Manufacturing Firms in Nigeria. Science Journal of Business and Management. Vol. 8, No. 1, 2020, pp. 7-15.

doi: $10.11648 /$ j.sjbm.20200801.12

Received: December 26, 2019; Accepted: January 8, 2020; Published: January 31, 2020

\begin{abstract}
The study empirically analyzed the relationship between dividend policy and firm's financial characteristics with a particular focus to consumer goods manufacturing companies in Nigeria. It utilized annual time series secondary data obtained from annual report and financial statements of the selected firms for the period of ten (10) years (2009-2018). Dividend policy was operationalized by Dividend per Share (DPS) and Dividend Payout Ratio (DPR) while the financial characteristics considered were Return on Assets (ROA), Return on Equity (ROE), and Earnings per Share (EPS). Ex-post facto research design was adopted while analytical techniques employed were Pearson Product Moment Correlation (PPMC) and Pairwise Granger Causality analysis mechanism. Findings revealed that Dividend per Share (DPS) interacts positively with the selected firm's financial characteristics while there is a negative and insignificant relationship between Return on Assets (ROA), Return on Equity (ROE), and Dividend Payout Ratio (DPR) of the selected firms. A positive relationship was maintained between DPR and EPS for the period. Meanwhile, the link between ROA and DPS was significant at $5 \%$ level. More so, evidence from the pairwise granger causality test revealed that there is no directional relationship between dividend policy and financial performance of consumer goods manufacturing firms in Nigeria. On this background, the study suggested that the financial system be reformed to enhance the operational efficiency of the financial market so as to determine the profitability of quoted firms via the dividend policy channel. It was also recommended that Managers of consumer goods manufacturing firms in Nigeria should ensure that they have well-structured dividend policies in place as this will make the company shares attractive to investors and however lead to increased stock prices and enhanced profitability.
\end{abstract}

Keywords: Dividend Policy, Profitability, Pearson Correlation, Pairwise Granger Causality, Manufacturing Firm

\section{Introduction}

The connotation between financial performance and dividend policy of firms has faced unresolved debate by researchers for a considerable period of time. From the extensive literature, it was ascertained that the ability of a firm to pay dividend is substantially reliant on the firm's profitability for the period. However, Amidu (2007) noted that dividend policy is one of the essential financial decisions that corporate managers encounter, and a micro prudential determinant of firms' profitability that facilitate the achievement of the organizational goals such as maximization of shareholders' wealth [1].

Optimal dividend policy requires that management allocates payout ratio that will guarantee the maximization of shareholders wealth through the vehicle of increased market value of the firm and its shares [2]; and companies with high dividend payout occasioned by high earnings are priced high on the Nigerian capital market.

According to Anike (2014), dividend payment provides cash flow to the shareholders but reduces the firm's resources for investment [3]. A firm's dividend policy can reduce agency problems between managers and shareholders and, in turn, enhance the firm's value to shareholders. It can take into consideration the different circumstances of its shareholders and in turn, enhance the firm's value to these shareholders [4].

Payment of dividends sends signals to shareholders that the firm is liquid and financially stable. It serves as income stream and thus maximizes shareholders' wealth [5]. A firm's 
value and performance is therefore enhanced through higher returns from optimal investments. By paying dividends to shareholders, free cash flows are reduced and thus managers have no opportunity to make sub-optimal investments [6]. In view of these, this study is focused on the effect of dividend policy on firm financial performance of consumer goods manufacturing firms in Nigeria. The factors under consideration in this study were; dividend yield, dividend payout, total assets, leverage and turnover.

\section{Review of Related Literature}

\subsection{Theoretical Review}

The theoretical review in which this study is underpinned include the Agency cost and Gordon theory.

\subsubsection{Agency Costs}

The Agency costs theory by Jensen and Meckling (1976) states that agents are supposed to run the corporation efficiently and effectively on behalf of shareholders and maximize shareholders wealth [7]. The agency cost theory suggests that, dividend policy is determined by agency costs arising from the divergence of ownership and control. Agency cost arises due to the monitoring of agents' activities by the principals to ensure the shareholders' wealth maximization. Firms pay dividend to the shareholders to minimize agency cost; because dividend payment will reduce the cash available to agents, therefore they cannot misuse it. Managers may not always adopt a dividend policy that is value-maximizing for shareholders but would choose a dividend policy that maximizes their own private benefits. Making dividend payouts which reduces the free cash flows available to the managers would thus ensure that managers maximize shareholders' wealth rather than using the funds for their private benefits [8].

The agency theory noted that management can invest shareholder's fund for personal interest rather than maximizing shareholders wealth [9].

\subsubsection{Gordon Theory}

This theory promulgated the concept of dividend relevance in the valuation of the market value of shares. The Gordon's model is known for its mathematical models in calculating the market value of a company's share. The model equates the market value of a company to present value of future streams of dividends. The variables taken into cognizance when determining the market value of a company include dividends, the cost of fund and expected growth rate. The theory maintained that dividend payout ratio, the interplay of the rate of returns and cost of capital, to a greater extent, influences the market value per share of a company.

The Gordon theory is based on the following assumptions: absence of debt in capital structure of the firm; investments are financed through retained earnings, no external financing; there is no tax and the absence of business risk. Dividend policy according to Gordon theory, impacts the company in the following circumstances. i. If the rate of return is higher than the cost of fund, profits are reinvested for future growth rather than distributing it as a dividend.

ii. If the internal rate of return is same as the cost of the fund, reinvestment of earnings or payment of dividends out of earnings makes no difference.

iii. If the rate of return is lower than the cost of fund, the firm distributes profits in the form of a dividend.

\subsection{Empirical Review}

Olarewaju, Migiro and Sibanda (2018) examined the causal relationship between dividend payout, retention policy and financial performance in commercial banks in 30 SubSaharan African countries [10]. The study covered 250 commercial banks in the Sub-Saharan African countries for the period of 2006 to 2015. Empirical results of the vector error correction block exogeneity Wald test and Pairwise Granger causality test revealed that only retention policies granger cause performance (ROA), even though both major policies posit a positive relationship with performance (ROA) in the Vector Error Correction Model estimate.

Agilebu (2019) employed descriptive and longitudinal design to examine the effect dividend decision and economic value added of quoted Nigeria manufacturing firms [11]. Secondary data from financial statement of 15 quoted manufacturing firms were used. Result revealed a 75 percent variation from the fixed effect results on economic value added of the manufacturing firms. Beta coefficient of the predictor variables found that dividend yield have negative effect on economic value added while dividend per share, dividend payout ratio and retention ratio have positive and significant effect on economic value added of the quoted manufacturing firms.

Using correlated random effects-Hausman test technique with the aid of E-view statistical package and regression analysis, Ubaka (2017) examined the effect of corporate dividend policy on the firm performance of conglomerate firms listed on the floor of the Nigeria stock exchange [12]. It covered the period from 2012-2016 and a sample of three conglomerate firms collected from a population size of seven listed conglomerate firms in Nigeria. The regression result showed that firm size, dividend payout, profit after tax and firm age are not significant in determining performance while corporate governance is significant in determining performance of firms in the conglomerate industry in Nigeria.

Uwuigbe, Jafaru and Ajayi (2012) employed ordinary least squares regression analysis technique to investigate the relationship between dividend policy and firm performance among listed firms' in Nigerian Stock Exchange for the periods of 2006-2010 [13]. The finding showed that there is a significant positive association between the performance of firms and the dividend payout of the sampled firms in Nigeria. Also, ownership structure and firm's size has a significant impact of the dividend payout of the selected firms.

Okafor, Ugwuegbe, Ugochukwu and Ezeaku (2016) 
employed pooled panel least square model to investigate the effect of board interest on dividend policy of Nigerian manufacturing sector for the period of 2009 to 2015 [14]. The result revealed that board interest has a negative and insignificant impact on dividend payout of the firms under consideration. Also, ownership concentration has a positive but insignificant effect on dividend payout of the Nigerian manufacturing firms while firm size was found to have a positive and significant effect on dividend payout among Nigerian manufacturing firms.

Muhammad and Muhammad (2016) used ordinary least square regression model to investigate the determinants of dividend payout of Oil and Gas industry listed on Karachi Stock Exchange (KSE) in Pakistan [15]. The study covered the period from 2008 to 2014 and found that financial leverage, sales growth and business risks were the key determinants of dividend payout of Oil and Gas industry in Pakistan. Particularly, it was shown that financial leverage and business risk have significant negative effect on dividend payout while sales growth has favorable positive impact on dividend payout. Also, there is a significant positive link of profitability and firm size with dividend payout whereas government ownership is negatively associated with dividend payout. Investment opportunities, liquidity and managerial ownership showed insignificant relationship with dividend payout.

Adesina, Uwuigbe, Uwuigbe, Asiriuwa and Oriabe (2017) examined the effect of dividend policy on share price valuation in the Nigerian banks, with a particular reference to four major banks in Nigeria, namely; Access Bank, First Bank, United Bank for Africa and Guarantee Trust Bank [16]. The study employed the Ordinary Least Square (OLS) regression mechanism and found that a significant positive relationship exist between earnings per share and market price of Nigerian banks.

Odum, Omeziri and Egbunike (2019) employed Panel Ordinary Least Square Regression Techniques to examine the impact of dividend payout ratio on the value of firms [17]. The study focused on breweries and beverage companies listed on the Nigerian stock exchange for the periods of 2007-2016. Findings revealed that profitability ratio and leverage ratio positively and significantly impact on value of the firm. This implies that only the variables of firm leverage, and Profit after Tax are significant factors that drives firm value in both breweries and beverages companies among listed companies in Nigeria.

Using the Ordinary Least Squares Method, Olabisi, Faberu and Onyekuwuluje (2017) examined the determinants of dividend policy among Nigerian listed consumer goods manufacturing companies in Nigeria [5]. The study used seven (7) randomly selected consumer goods manufacturing companies from twenty-seven (27) listed companies on the Nigeria Stock Exchange (NSE) as at 2016. Empirical result provided that there is a negative and significant relationship between profitability and dividend policy. Also, a positive and significant relationship exists between liquidity and dividends of the firms.

Khan, Nadeem, Islam, Salman and Gill (2016) used OLS technique to examine the impact of dividend policy on firm performance in Pakistan from 2010-2015 [4]. The findings showed that there is a positive relationship between return on assets, dividend policy, and growth in sales. Also, dividend payout ratio and leverage have significant negative relationship with the return on equity of the firms.

Murekefu and Ouma (2012) examined the relationship between dividend payout and firm performance using data obtained from the annual reports of companies listed in the Nairobi Securities Exchange for a nine year period (2002 to 2010) [18]. Analytical tools employed were descriptive statistics and Pearson correlation technique. Result showed that dividend payout was a major factor affecting firm performance.

Akani and Sweneme (2016) examined the impact of dividend policy and the profitability of selected quoted manufacturing firms in Nigeria from 1981-2014 [9]. Analytical techniques employed were multiple regression analysis considering multi-colinearity test, co-linearity, and Durbin Watson statistics. Findings revealed that all the independent variables have positive relationship with the dependent variables except dividend yield.

By employing ordinary least square regression, Alam, Miah and Karim (2016) investigated the key determinant factors affecting share prices in the capital Market in Bangladesh [19]. The study used panel data of 7 companies in cement industry listed in the Dhaka Stock Exchange (DSE) for the periods of 2006-2015. Result showed that EPS, NAVPS, P/E and CPI are significantly instrumental for stock prices in the cement industry while GDP and IRS were found to be insignificant in determining stock prices in cement industry.

Shilo and Mohammed (2014) empirically examined the effect of dividend payout ratio on stock prices of quoted Deposit Money Banks in Nigeria [20]. The Authors utilized ordinary least square regression technique and provided evidence that dividend payout insignificantly affects stocks prices of quoted banks in Nigeria.

Troudi and Milhem (2013) examined the relationship between cash dividends, retained earnings and the stock prices controlling for earnings per share and financial leverage in the Jordanian stock market [21]. The population constituted all the listed firms on the Amman Stock Exchange for the period of 2005-2010. Simple regression analysis technique was employed while result showed a positive and significant relationship between cash dividends, retained earnings, earnings per share and stock price while financial leverage was found to interact positively but insignificantly with stock prices within the period.

Miko and Kamardin (2015) examined the impact of ownership structure on dividend policy of eight conglomerate firms consisting of 80 firm-observations in Nigeria [22]. The study spanned for the period of 2001-2010; and utilized pooled panel data regression analysis technique. Finding revealed that there is a positive association between dividend pay-out and institutional ownership as well as block-holders ownership. The result also revealed that management ownership has a negative association with firms dividend 
pay-out indicating that dividend policy is used by managers to expropriate the shareholders wealth.

Using a random sample of thirty listed companies in the Nigerian Stock Exchange for the period of 2006 to 2010, Odia and Ogiedu (2013) empirically investigated the relationship between payout policy, agency and corporate governance in Nigeria [23]. A panel OLS regression analysis was employed to analyze the data collected. The result showed that firms' investment opportunities and leverage have significant impact on the dividend payout. The corporate governance mechanisms comprising the CEO shareholdings, directors' shareholdings and the institutional ownership have positive but non-significant impact on the dividend payout. This means that the insiders and institutional ownership may not complete mitigate the agency conflicts associated with effective dividend payout policy. Moreover, the negative and non-significant association of cash-flow and growth of firms may indicate more retentions by directors which may be expropriated by firm's management through salaries and other compensations or invested in projects to satisfy personal benefits at the dispense of the shareholders.

Agyemang-Badu (2013) examined the dividend policy drivers of listed financial firms in Ghana for the period 20052009 [24]. The random and fixed effect technique was used to analyze the data obtained from the annual reports of the firms considered. The finding showed that firm age and liquidity enhance dividend payment as they depicted a positive significant relationship. However, profitability and collateral could not explain dividend payment.

Mehmood, Hunjre and Chani (2019) examined the impact of corporate diversification and financial structure on the firms' financial performance [25]. Data was collected from 520 manufacturing firms from Pakistan, India, Sri Lanka, and Bangladesh from 2004-2017 and was analyzed using twostep dynamic panel approach. The finding revealed that product diversification and geographic diversification significantly affected the firms' financial performance. Also, dividend policy and capital structure had a significant impact on the firm's financial performance.

Oladipupo and Ibadin (2013) examined the relationship between working capital management and dividend policy of listed manufacturing companies in Nigeria [26]. The study covered the period from 2002-2006. Using the ordinary least squares regression analysis technique, the finding revealed that profitability and working capital management (in terms of net trade cycle) have positive and insignificant relationship with dividend policy while earnings and firm growth are negatively and insignificantly related with dividend policy.

Bushuru, Basweti and Mukonyi (2015) examined the impact of working capital management on dividend payout ratio in Kenya [27]. The study used data from listed firms on the Nairobi securities exchange for the period 2006-2013. The results from the multiple regression analysis established that working capital management (in terms of cash conversion cycle (CCC) and accounts payable period (APP) have significant positive relationship with dividend payout ratio. On the other hand, working capital management (in terms of accounts receivable collection period (ACP) and inventory collection period (ICP)) interacts negatively and significantly with dividend payout ratio.

In another study, Olang and Grace (2017) examined the impact of working capital management on dividend payout ratio in Kenya using OLS regression to analyze the data collected [28]. The result revealed that working capital management (measured by cash management, inventory management, and accounts receivables) have positive and significant impact on firms' dividend payout policy.

Kaźmierska-Jóźwiak (2015) investigated the factors motivating dividend payment of non-financial firms in Polish [29]. Using a panel dataset covering from 2000-2012, the results from the random effects estimation revealed that firms' profitability and leverage are negatively and significantly related to dividend policy in Polish.

Applying the fixed and random effects, pooled least squares model analytical techniques, Yusof and Ismail (2016) used 147 public listed companies in Malaysia to analyze the significant factors influencing dividend policy [30]. The finding showed that earnings, debt, firm size, investment and firms with a large number of shareholders have a significant effect on dividend payout policy.

Elmagrhia, Ntim, Crossley, Malagila, Fosu, and Vu (2017) examined the extent to which corporate board characteristics influence the level of dividend payout ratio using a sample of UK small and medium-sized enterprises (SMEs) from 2010 to 2013 listed on the Alternative Investment Market using multivariate regression techniques, including estimating fixed effects, lagged effects and twostage least squares regressions to analyze the data obtained [31]. The finding revealed that board size, frequency of board meetings, board gender diversity and audit committee size have a significant relationship with the level of dividend payout. Audit committee size and board size have a positive association with the level of dividend payout, whilst the frequency of board meetings and board gender diversity has a significant negative relationship with the level of dividend pay-out.

Eniola and Akinselure (2016) examined the impact of dividend policy on earnings of selected quoted companies in Nigeria [32]. The secondary data was obtained through the internet from stock broking firm's online database. Multiple regression and Durbin-Watson statistics were used in the hypothesis considered in this study. The finding revealed a significant relationship between dividend and market value though, this relationship was ascertained to only exist between earning per share and dividend yield. Other proxies of dividend policy did not show any relationship.

\section{Methodology}

The study adopted ex-post facto research design considering that the research is an 'after the fact' study. The period covered was 2009-2018; while the annual time series secondary data used were extracted from the annual accounts 
and financial statements of the selected quoted firms.

The Jarque-Bera statistic proposed by Bera and Jarque (1982) provides a formal assessment of how much the skewness and kurtosis deviate from the normality assumptions of symmetry (zero skewness) and a fixed peak of three [33]. The Jarque-Bera (JB) test statistics is calculated as:

$$
\mathrm{JB}=\frac{1}{6}\left[S^{2} \frac{(K-3)^{2}}{4}\right]
$$

Where;

$\mathrm{S}=\frac{1}{T} \sum_{i=1}^{T}\left(\frac{X_{i}-\bar{X}}{\widehat{\sigma}}\right)^{3}$ is the sample skewness. This third moment or skewness is an indicator of the asymmetry in the distribution.

$\mathrm{K}=\frac{1}{T} \sum_{i=1}^{T}\left(\frac{X_{i}-\bar{X}}{\widehat{\sigma}}\right)^{4}$ is the sample kurtosis. The fourth moment or kurtosis is a measure of the peakness of the distribution.

$\mathrm{T}$ is the sample size, $\bar{X}$ is the sample mean and $\hat{\sigma}$ is the estimated standard deviation.

JB statistics follows chi-square $\chi^{2}$ distribution with two degrees of freedom for large sample. The null hypothesis in this test is that the data follow normal distribution.

The study employed the Pearson Product Moment Correlation Coefficient (PPMCC) to determine the strength and significance of the relationship

$$
\mathrm{r}=\frac{\operatorname{Cov}\left(X_{1}, X_{2}\right)}{\sqrt{\left(\operatorname{Var}\left(X_{1}\right)\right)\left(\operatorname{Var}\left(X_{2}\right)\right)}}=\frac{\sum_{i=1}^{n}\left[\left(X_{1}-\bar{X}_{1}\right)\left(X_{2}-\bar{X}_{2}\right)\right]}{\sqrt{\left[\sum_{i=1}^{n}\left(X_{1}-\bar{X}_{1}\right)^{2}\right]\left[\sum_{i=1}^{n}\left(X_{2}-\bar{X}_{2}\right)^{2}\right]}}
$$

Where,

$r$ is the correlation coefficient,

$\operatorname{Cov}\left(X_{1}, X_{2}\right)=\sum_{i=1}^{n}\left[\left(X_{1}-\bar{X}_{1}\right)\left(X_{2}-\bar{X}_{2}\right)\right] \quad$ is the covariance of $X_{1}$ and $X_{2}$ series,

$\operatorname{Var}\left(X_{1}\right)=\sum_{i=1}^{n}\left(X_{1}-\bar{X}_{1}\right)^{2}$ is the variance of $X_{1}$ series,

$\operatorname{Var}\left(X_{2}\right)=\sum_{i=1}^{n}\left(X_{2}-\bar{X}_{2}\right)^{2}$ is the variance of $X_{2}$ series, $n=$ sample size.

More so, the granger causality technique was used to estimate the cause-effect relationship between the two groups of variables under investigation. Generally, the Granger (1969) mechanism for causal or directional relationship between two variables is specified thus:

$$
X_{t}=\sum_{i=1}^{m} \delta_{1} X_{t-1}+\sum_{j=1}^{k} \beta_{1} \theta_{t-1}+\mu_{t}
$$

Where,

$\mathrm{X}=$ the variable whose causation is being appraised

$X_{t-1}=$ lagged values of the variable.

$\mu_{t}=$ Stochastic disturbance associated with the model. [34]

\section{Description of Model Variables}

Dividend per Share (DPS): This is ratio of dividends paid to the number of outstanding shares. It is the sum of declared dividends for every ordinary share issued. DPS are the amount of dividends that a publicly traded company pays per share of common stock, over their reporting period that they have issued. DPS may be used by individuals who are evaluating various stocks to invest in and prefer companies who pay dividends [35]. DPS measures dividend on per share basis. It is given by the formula: DPS $=\frac{\text { Dividends }}{\text { Number of Shares }} \times \frac{100}{1}$

Dividend Payout Ratio (DPR): The dividend payout ratio measures the percentage of dividends a company pays out relative to its earnings per share (EPS). The payout ratio is used in fundamental analysis to determine whether a company could continue paying dividends to its shareholders. The payout ratio is calculated by dividing a company's dividends per share by its earnings per share. A low payout ratio is generally favourable to a high payout ratio. A high ratio indicates that a company is paying a large portion of its earnings to its shareholders; meanwhile, a low ratio may indicate that a company is reinvesting a large portion of its earnings into the company [36]. Dividend Payout Ratio (DPR) is mathematically computed as: DPR = $\frac{\text { Dividend per Share }}{\text { Earnings per Share }} \times \frac{100}{1}$

Return on Assets (ROA): The Return on Assets (ROA) measures the ratio of net income to total assets of a company. It is usually expressed in percentage. Return on Assets (ROA) is an accounting-based measure of profitability that gauges the operating and financial performance of the firm. It shows how well a company utilizes its assets, by determining how profitable a company is relative to its total assets. Mathematically, the Return on Assets (ROA) is calculated by: Return on Assets $(\mathrm{ROA})=\frac{\text { Net Income }}{\text { Total Asset }} \times 100$

Return on Equity (ROE): This is a ratio of Net Income after Taxes divided by Total Equity Capital. It measures how profitable a company is by comparing its net income to its average shareholders' equity. In a clearer term, the Return on Equity (ROE) is the ratio between the net profit after tax and total equity [37]. It also indicates how well a company's management is deploying the shareholders' capital hence it determines the benefits of the investments made. It is a pull factor for investors to invest. The higher the ROE, the better the company in terms of profit generation; hence, a falling ROE is usually a problem. Return on Equity (ROE) of a firm is calculated by dividing net income by the total number of shareholders equity. Mathematically, the Return on Equity $(\mathrm{ROE})=\frac{\text { Net Income }}{\text { Shareholders Equity }} \times 100$.

Earnings per Share (EPS): This measures the portion of a company's earnings, net of taxes and preferred stock dividends, that is allocated to each share of common stock. According to Ekwe and Inyiama (2014), EPS is used as a barometer to gauge a company's profitability per unit of shareholder ownership [38]. It is usually computed as the ratio of net income (usually quarterly or annually) to the total number of shares outstanding for the period. Mathematically, Earnings per Share (usually in kobo) can be expressed as: $\mathrm{EPS}=\frac{\text { Net Income }}{\text { Number of Shares in units }} \times 100$.

\section{Data Presentation, Analysis and Interpretation of Results}

Data Presentation

Numerical data used for the study are presented in tables 1 to 5 below. 
Table 1. Nigerian Breweries Plc.

\begin{tabular}{llllll}
\hline YEARS & ROA (\%) & ROE (\%) & EPS in Kobo & DPS (\%) & DPR (\%) \\
\hline 2009 & 26.09 & 59.93 & 369 & 74.61 & 0.78 \\
2010 & 26.52 & 60.46 & 401 & 71.33 & 0.64 \\
2011 & 19.50 & 48.97 & 508 & 78.36 & 1.02 \\
2012 & 15.01 & 40.73 & 503 & 10.13 & 2.23 \\
2013 & 16.42 & 36.93 & 570 & 16.30 & 2.44 \\
2014 & 12.04 & 24.50 & 562 & 32.16 & 3.13 \\
2015 & 10.67 & 22.09 & 482 & 47.97 & 3.02 \\
2016 & 7.72 & 17.13 & 358 & 39.77 & 3.51 \\
2017 & 8.62 & 18.53 & 413 & 51.04 & 3.78 \\
2018 & 4.99 & 11.64 & 243 & 48.22 & 2.99 \\
\hline
\end{tabular}

Source: Author's computation from Annual Reports of Nigerian Breweries Plc (2009-2018)

Table 2. Guinness Breweries Plc.

\begin{tabular}{llllll}
\hline YEARS & ROA (\%) & ROE (\%) & EPS in Kobo & DPS (\%) & DPR (\%) \\
\hline 2009 & 18.33 & 42.95 & 918 & 0.65 & 2.17 \\
2010 & 16.64 & 40.17 & 931 & 0.20 & 3.60 \\
2011 & 19.44 & 44.50 & 1,216 & 0.21 & 2.76 \\
2012 & 13.41 & 36.81 & 864 & 0.18 & 2.05 \\
2013 & 9.80 & 25.77 & 793 & 0.33 & 1.87 \\
2014 & 7.23 & 21.25 & 636 & 0.27 & 1.97 \\
2015 & 6.38 & 16.12 & 518 & 0.38 & 2.00 \\
2016 & $(1.47)$ & $(4.84)$ & $(134)$ & 1.01 & 2.33 \\
2017 & 1.32 & 4.48 & 128 & 0.97 & 2.15 \\
2018 & 4.38 & 7.67 & 330 & 0.54 & 2.08 \\
\hline
\end{tabular}

Source: Author's computation from Annual Reports of Guinness Breweries Plc (2008-2018)

Table 3. International Breweries Plc.

\begin{tabular}{llllll}
\hline YEARS & ROA (\%) & ROE (\%) & EPS in Kobo & DPS (\%) & DPR (\%) \\
\hline 2009 & $(5.61)$ & 70.58 & $(14)$ & 1.64 & 2.17 \\
2010 & 22.37 & 116.89 & 133 & 0.96 & 3.60 \\
2011 & $(15.21)$ & $(976.28)$ & $(103)$ & 1.01 & 2.98 \\
2012 & 6.19 & 17.81 & 35 & 0.87 & 2.14 \\
2013 & 10.10 & 29.02 & 71 & 1.21 & 4.11 \\
2014 & 8.64 & 18.68 & 64 & 1.67 & 2.13 \\
2015 & 6.45 & 16.00 & 59 & 1.86 & 3.78 \\
2016 & 7.92 & 18.95 & 81 & 1.19 & 3.56 \\
2017 & 2.30 & 7.45 & 31 & 1.53 & 2.76 \\
2018 & $(3.76)$ & $(11.00)$ & $(45)$ & 0.96 & 3.63 \\
\hline
\end{tabular}

Source: Author's computation from Annual Report of International Breweries Plc (2008-2018)

Table 4. Cadbury Nig. Plc.

\begin{tabular}{llllll}
\hline YEARS & ROA (\%) & ROE $(\%)$ & EPS in Kobo & DPS (\%) & DPR (\%) \\
\hline 2009 & $(4.53)$ & $(9.03)$ & $(56)$ & 0.55 & 1.62 \\
2010 & 10.14 & 8.98 & 37 & 0.56 & 1.96 \\
2011 & 10.93 & 22.17 & 137 & 1.64 & 0.29 \\
2012 & 8.62 & 17.27 & 107 & 2.96 & 0.47 \\
2013 & 12.74 & 22.92 & 192 & 1.01 & 1.51 \\
2014 & 7.42 & 16.76 & 106 & 0.87 & 1.32 \\
2015 & 4.06 & 9.39 & 61 & 1.21 & 1.63 \\
2016 & $(1.04)$ & $(2.68)$ & $(16)$ & 1.67 & 0.75 \\
2017 & 1.06 & 2.55 & 16 & 1.86 & 0.09 \\
2018 & 2.99 & 6.49 & 44 & 1.93 & 0.13 \\
\hline
\end{tabular}

Source: Author's computation from Annual Reports of Cadbury Nig. Plc (2009-2018)
Table 5. Nestle Foods Nig. Plc.

\begin{tabular}{llllll}
\hline YEARS & ROA (\%) & ROE (\%) & EPS in Kobo & DPS (\%) & DPR (\%) \\
\hline 2009 & 20.71 & 92.79 & 1,481 & 7.19 & 0.63 \\
2010 & 20.72 & 84.59 & 1,908 & 4.55 & 0.43 \\
2011 & 21.22 & 71.07 & 2,081 & 7.61 & 0.78 \\
2012 & 23.76 & 61.83 & 2,667 & 11.33 & 0.64 \\
2013 & 20.57 & 54.83 & 2,808 & 8.36 & 1.02 \\
2014 & 20.96 & 61.87 & 2,805 & 5.13 & 2.23 \\
2015 & 19.91 & 62.45 & 2,955 & 6.30 & 2.44 \\
2016 & 4.67 & 25.67 & 1,000 & 12.16 & 3.13 \\
2017 & 22.97 & 75.15 & 4,255 & 15.97 & 3.02 \\
2018 & 26.49 & 85.64 & 5,426 & 18.01 & 3.26 \\
\hline
\end{tabular}

Source: Author's computation from Annual Reports of Nestle Foods Nig. Plc (2009-2018)

Tables 1 through 5 above shows that the dataset obeys the law of time series data as it exhibit a random movement pattern over the period.

Table 6. Description of research Variables.

\begin{tabular}{llllll}
\hline $\begin{array}{l}\text { Estimated } \\
\text { Parameters }\end{array}$ & ROA (\%) & ROE (\%) & $\begin{array}{l}\text { EPS } \\
\text { (kobo) }\end{array}$ & DPS (\%) & DPR (\%) \\
\hline Mean & 10.73600 & 13.09200 & 778.7000 & 11.96800 & 2.094600 \\
Median & 9.950000 & 22.54500 & 363.5000 & 1.670000 & 2.145000 \\
Maximum & 26.52000 & 116.8900 & 5426.000 & 78.36000 & 4.110000 \\
Minimum & -15.21000 & -976.2800 & -134.0000 & 0.180000 & 0.090000 \\
Std. Dev. & 9.415077 & 145.6312 & 1174.120 & 20.71028 & 1.113845 \\
Skewness & -0.266798 & -6.438866 & 2.171752 & 2.068347 & -0.125017 \\
Kurtosis & 2.711373 & 44.37388 & 7.598275 & 6.133940 & 1.984993 \\
Jarque-Bera & 0.766730 & 3911.738 & 83.35449 & 56.11210 & 2.276575 \\
Probability & 0.681564 & 0.000000 & 0.000000 & 0.000000 & 0.320367 \\
Sum & 536.8000 & 654.6000 & 38935.00 & 598.4000 & 104.7300 \\
Sum Sq. Dev. & 4343.540 & 1039213. & 67549313 & 21016.88 & 60.79184 \\
Observations & 50 & 50 & 50 & 50 & 50 \\
\hline
\end{tabular}

Source: Author's Eviews 10 Result

From the descriptive statistics result, it was ascertained that the variables are explosive and unstable over the period, of which course, they cannot be confidently predicted. The mean value of ROA of the selected firms was $10.74 \%$; Mean ROE was $13.09 \%$, EPS stood at 778 kobo; while DPS and DPR stood at average of $11.97 \%$ and $2.09 \%$ respectively.

Looking at the peakedness as well as symmetric distribution of the data series as estimated by the distribution measures (Skewness and Kurtosis), the researcher deduced that series of ROA, ROE, and DPR are negatively skewed while EPS and DPS are skewed to the right. There is excess kurtosis in series of ROE, EPS, and DPS for the period. The effectiveness of the excess kurtosis was confirmed by the Jarque-Bera goodness of fit test (with p-values $<0.05$ ). It shows that the series of ROE, EPS, and DPS do not follow normal distribution.

Table 7. Correlation Matrix.

\begin{tabular}{|c|c|c|c|c|}
\hline \multicolumn{5}{|c|}{ Covariance Analysis: Ordinary } \\
\hline \multicolumn{5}{|c|}{ Sample: 2009 - 2018} \\
\hline \multicolumn{5}{|c|}{ Included observations: $\mathbf{5 0}$} \\
\hline $\mathbf{X}_{1}$ & $\mathbf{X}_{2}$ & Correlation & t-Statistic & Probability \\
\hline ROA & ROA & 1.000000 & ----- & ----- \\
\hline ROE & ROA & 0.534999 & 4.387251 & 0.0001 \\
\hline ROE & ROE & 1.000000 & ----- & ----- \\
\hline
\end{tabular}




\begin{tabular}{lllll}
\hline \multicolumn{5}{l}{ Covariance Analysis: Ordinary } \\
\hline \multicolumn{4}{l}{ Sample: 2009 - 2018 } \\
\hline \multicolumn{4}{l}{ Included observations: $\mathbf{5 0}$} \\
\hline $\mathbf{X}_{\mathbf{1}}$ & $\mathbf{X}_{\mathbf{2}}$ & Correlation & t-Statistic & Probability \\
\hline EPS & ROA & 0.640379 & 5.776471 & 0.0000 \\
EPS & ROE & 0.229361 & 1.632580 & 0.1091 \\
EPS & EPS & 1.000000 & ---- & ---- \\
DPS & ROA & 0.354426 & 2.626001 & 0.0116 \\
DPS & ROE & 0.107973 & 0.752455 & 0.4555 \\
DPS & EPS & 0.029951 & 0.207603 & 0.8364 \\
DPS & DPS & 1.000000 & ---- & ---- \\
DPR & ROA & -0.150826 & -1.057048 & 0.2958 \\
DPR & ROE & -0.124821 & -0.871605 & 0.3878 \\
DPR & EPS & 0.006700 & 0.046418 & 0.9632 \\
DPR & DPS & -0.022040 & -0.152732 & 0.8793 \\
DPR & DPR & 1.000000 & ---- & ---- \\
\hline
\end{tabular}

Source: Author's Eviews 10 Result

From the correlation estimate, there is a positive relationship Dividend per Share (DPS) and the selected financial indicators: Return on Assets (ROA), Return on Equity (ROE), and Earnings per Share (EPS) of consumer goods manufacturing firms. Meanwhile, Dividend Payout Ratio (DPR), have mixed relationship with the selected financial performance characteristics of the firms. Particularly, there is a negative relationship between ROA, ROE, and DPR while a positive relationship between DPR and EPS of the selected firms.

Table 8. Regression Result.

\begin{tabular}{|c|c|c|c|}
\hline \multicolumn{4}{|l|}{ Pairwise Granger Causality Tests } \\
\hline \multicolumn{4}{|l|}{ Sample: 20092018} \\
\hline \multicolumn{4}{|l|}{ Lags: 2} \\
\hline Null Hypothesis: & Obs & F-Statistic & Prob. \\
\hline ROE does not Granger Cause ROA & 40 & 3.04980 & 0.0601 \\
\hline ROA does not Granger Cause ROE & & 11.4356 & 0.0002 \\
\hline EPS does not Granger Cause ROA & 40 & 3.38997 & 0.0451 \\
\hline ROA does not Granger Cause EPS & & 0.58556 & 0.5622 \\
\hline DPS does not Granger Cause ROA & 40 & 0.03638 & 0.9643 \\
\hline ROA does not Granger Cause DPS & & 0.08744 & 0.9165 \\
\hline DPR does not Granger Cause ROA & 40 & 0.27560 & 0.7608 \\
\hline ROA does not Granger Cause DPR & & 1.46947 & 0.2439 \\
\hline EPS does not Granger Cause ROE & 40 & 1.45475 & 0.2472 \\
\hline ROE does not Granger Cause EPS & & 0.04273 & 0.9582 \\
\hline DPS does not Granger Cause ROE & 40 & 0.30061 & 0.7423 \\
\hline ROE does not Granger Cause DPS & & 0.04119 & 0.9597 \\
\hline DPR does not Granger Cause ROE & 40 & 1.29667 & 0.2863 \\
\hline ROE does not Granger Cause DPR & & 3.37510 & 0.0457 \\
\hline DPS does not Granger Cause EPS & 40 & 0.05345 & 0.9480 \\
\hline EPS does not Granger Cause DPS & & 0.12554 & 0.8824 \\
\hline DPR does not Granger Cause EPS & 40 & 0.11711 & 0.8898 \\
\hline EPS does not Granger Cause DPR & & 1.20394 & 0.3121 \\
\hline DPR does not Granger Cause DPS & 40 & 0.93091 & 0.4037 \\
\hline DPS does not Granger Cause DPR & & 1.61535 & 0.2133 \\
\hline
\end{tabular}

Source: Researchers' E-views 10.0 Output

The pairwise granger causality test result shows that there is no causal relationship between dividend policy (proxy by DPS and DPR) and financial performance characteristics of the selected consumer goods manufacturing firms. However, there is a uni-directional causality running from ROE to DPR and from ROA to ROE of the firms.

\section{Conclusion}

This study empirically investigated the relationship between dividend policy and financial performance characteristics of consumer goods manufacturing firms in Nigeria. The lesson emerging from the empirical investigation was that there is a week positive relationship between dividend per share and financial performance indices of consumer goods manufacturing firms while the link between dividend payout ratio and financial performance indices of the firm is negative and insignificant. This implies that the interaction between dividend policy and financial standing of the firms is dependent on the proxy for dividend policy and financial performance indicator used. On this standing, the study suggested that:

\section{Recommendations}

1) Managers of consumer goods manufacturing firms in Nigeria should ensure that they comply with relevant and required policy of paying dividend in order to avoid consequent effect of dividend policy on the sustainable growth of the sub-sector.

2) The financial system should be reformed to enhance the operational efficiency of the financial market to determine the profitability of quoted firms via the dividend policy channel.

3) Managers of consumer goods manufacturing firms in Nigeria should ensure that they have well-structured dividend policies in place as this will make the company shares attractive to investors and however lead to increased stock prices and enhanced profitability.

4) The management of the quoted firms should be efficient and effective to achieve increased profitability of the quoted manufacturing firms.

5) There should be consistent dividend policy that will maximize shareholders wealth without mortgaging the profitability objectives of the firms.

6) Managers of the consumer goods manufacturing firms in Nigeria who have the intention of reviewing their dividend policies should also consider their shareholders.

\section{References}

[1] Amidu, M. (2007). How does dividend policy affect the performance of firms in Ghana stock exchange? Journal of Investment Management and Financial Innovations, 4 (2), 6-8.

[2] Ezirim, B. C. (2005). Finance Dynamics: Principle, Techniques and Application. Markowitz Centre for Research and Development.

[3] Anike, E. A. (2014). The impact of dividend policy and earnings on stock prices of Nigeria banks. Department of Banking and Finance, Faculty of Business Administration, University of Nigeria, Nsukka, Enugu State. 
[4] Khan, M. N., Nadeem, B., Islam, F., Salman, M. \& Gill, H. M. I. S. (2016). Impact of dividend policy on firm performance: Empirical evidence from Pakistan stock exchange. American Journal of Economics, Finance and Management, 2 (4), 28-34.

[5] Olabisi, J., Faberu, O. \& Onyekuwuluje, T. P. (2017). Determinants of dividend policy among Nigerian listed consumer goods manufacturing companies. Journal of Humanities, Social Sciences and Crative Arts, 92-104.

[6] Bartram, S. M. et al. (2009). Agency Conflicts and Corporate Payout Policies: A Global Study

[7] Jensen, M. C. \& Meckling, W. H. (1976). Theory of dividend policy in Jordan: An application of the firm: Managerial behaviour, agency costs and Tobit model. Journal of Economic \& Administrative ownership structure, 30 (4).

[8] DeAngelo, H., De Angelo, L., \& Stulz, R. (2006). Dividend policy and the earned/contributed capital mix: a test of the life-cycle theory. Journal of Financial Economics, 81, 227254.

[9] Akani, H. W. \& Sweneme, Y. (2016). Dividend policy and the profitability of selected quoted manufacturing firms in Nigeria: An empirical analysis. Journal of Finance and Accounting, 4 (4), 212-224

[10] Olarewaju, O. M., Migiro, S. O. \& Sibanda, M. (2018). Dividend payout, retention policy and financial performance in commercial banks: any causal relationship? Studia Universitatis Babeș-Bolyai Oeconomica, 63 (1), 37-62.

[11] Agilebu, O. M. (2019). Dividend decision and economic value added of quoted Nigeria manufacturing firms. American Economic \& Social Review, 5 (2), 45-59.

[12] Ubaka, I. E. (2017). Corporate dividend policy and firm performance: Nigeria evidence from quoted conglomerate firms. 2017 National Conference of School of Management Studies, Ilaro, Ogun State, 1-19.

[13] Uwuigbe, U., Jafaru, J. \& Ajayi, A. (2012). Dividend policy and firm performance: A study of listed firms in Nigeria. Accounting and Management Information Systems, 11 (3), 442-454.

[14] Okafor, I. G., Ugwuegbe, Ugochukwu, S. \& Ezeaku, H. C. (2016). The effect of board interest on dividend policy of Nigerian manufacturing sector. International Journal of Academic Research in Business and Social Sciences, 6 (8), 100-115.

[15] Muhammad, T. \& Muhammad, M. (2016). Determinants of dividend payout: Evidence from listed Oil and Gas Companies of Pakistan. The Journal of Asian Finance, Economics and Business, 3 (4), 25-37.

[16] Adesina, K., Uwuigbe, U., Uwuigbe, O. R., Asiriuwa, O. \& Oriabe, S. (2017). Dividend policy and share price valuation in the Nigerian banks. EuroEconomica, 36 (1).

[17] Odum, A. N., Odum, C. G., Omeziri, R. I. \& Egbunike, C. F. (2019). Impact of dividend payout ratio on the value of firm: A study of companies listed on the Nigerian Stock Exchange. Indonesian Journal of Contemporary Management Research, 1 (1), 26-34.

[18] Murekefu, T. M. \& Ouma, O. P. (2012). The relationship between dividend payout and firm performance: A study of listed companies in Kenya. European Scientific Journal, 8 (9),
199-215.

[19] Alam, S., Karim, R. \& Karim, A. (2016). Analysis on factors that affect stock prices: A study on listed cement companies at Dhaka stock exchange. Research Journal of Finance and Accounting, 7 (18), 93-113.

[20] Shilo, S. J., \& Mohammed, N. M. (2014). Effect of dividend payout on stock prices of quoted deposit money banks in Nigeria. Journal of Finance and Accounting Research, 6 (1), 100-109.

[21] Troudi, W. \& Milhem, M. (2013). Cash dividend, retained earnings and stock prices: Evidence from Jordan. Interdisciplinary Journal of Contemporary Research in Business, 4 (12), 585-599.

[22] Miko, N. U., \& Kamardin, H. (2015). Ownership structure and dividend policy of conglomerate firms in Nigeria. Academic Journal of Interdisciplinary Studies, 4 (2), 279-286.

[23] Odia, J. \& Ogiedu, K. O. (2013). Payout policy, agency conflict and corporate governance in Nigeria. Review of Public Administration and Management, 2 (3), 48-61.

[24] Agyemang-Badu, E. (2013). Determinants of dividend payout policy of listed financial institutions in Ghana. Research Journal of Finance and Accounting, 4 (7), 185-190.

[25] Mehmood, Hunjre, \& Chani, (2019). Impact of corporate diversification and financial structure on the firm performance: Evidence from South Asian Countries. Journal of Risk and Financial Management, 12 (49), 1-17.

[26] Oladipupo, A. O., \& Ibadin, P. O. (2013). Does working capital management matter in dividend policy decision? Empirical evidence from Nigeria. International Journal of Financial Research, 4 (4), 140-145.

[27] Bushuru, R. W., Basweti, A. K., \& Mukonyi, P. M. (2015). The relationship between working capital management and divided payout ratio of firms listed in Nairobi Securities Exchange. International Journal of Economics, Commerce and Management, 3 (11), 285-296.

[28] Olang, M. A., \& Grace, A. M. (2017). Effect of Working capital on the Dividend pay-out by firms firms listed at the Nairobi Securities Exchange, Kenya. International Journal of Finance and Banking Research, 3 (2), 23-33.

[29] Kaźmierska-Jóźwiak, B. (2015). Determinants of dividend policy: evidence from polish listed companies. Procedia economics and finance, 23, 473-477.

[30] Yusof, Y. \& Ismail, S. (2016). Determinants of dividend policy of public listed companies in Malaysia. Review of International Business and Strategy, 26 (1), 88-99.

[31] Elmagrhi, M. H., Ntim, C. G., Crossley, R. M., Malagila, J. K., Fosu, S. \& Vu, T. V. (2017). Corporate governance and dividend pay-out policy in UK listed SMEs: The effects of corporate board characteristics. International Journal of Accounting and Information Management, 25 (4), 459-483.

[32] Eniola, O. J. \& Akinselure, O. P. (2016). Impact of divided policy and earnings on selected Quoted companies in Nigeria. International Journal of Innovative Research and Development, 5 (6), 308-321.

[33] Bera, A. K. \& Jarque, C. M. (1982). Model specification tests: A simultaneous approach. Journal of Econometrics, 20, 59-82. 
[34] Granger, C. W. J. (1986). Development in the study of cointegrated economic variables. Oxford Bulletin of Economics and Statistics, 48, 213-227.

[35] Yusuf A., \& Al Qudah A. (2015). Stock Price Volatility and Dividend Policy in Jordanian Firms. Research Journal of Finance and Accounting, 6; 22.

[36] Enekwe C. I., Agu C. I., \& Eziedo K. N. (2015). The effect of financial leverage on financial performance: Evidence of quoted pharmaceutical companies in Nigeria. IOSR Journal of Economics and Finance. 5; 3; 17-25.
[37] Hansen D. R., \& Mowen M. M. (2012). Managerial Accounting. Issue 8. Salemba Four. Cengage Learning.

[38] Ekwe M. \& Inyiama O. (2014). Foreign Capital Flows and Growth of the Nigeria Economy: An Empirical Review. International Journal of Economics and Finance. 6; 4.

[39] Azhagaiah, R., \& Priya, S. N. (2008). The impact of dividend policy on shareholders' wealth. International Research Journal of Finance and Economics, 20, 180-187.

[40] Howatt, B. et al. (2009). Dividends, earnings volatility and information. Applied Financial Economics, 19 (7), 551-562. 